\title{
Quintessence of the forensic methodology for investigating illegal acts committed by foreign nationals
}

\author{
Eduard Vladimirovich Lantukh ${ }^{1 *}$, Sergey Viktorovich Petrakov ${ }^{2}$, Albina Vladimirovna \\ Bachieva $^{1}$, Victoria Eduardovna Shunk ${ }^{1}$, and Oksana Leonidovna Romanova ${ }^{1}$ \\ ${ }^{1}$ Saint Petersburg University of the Ministry of Internal Affairs of Russia, Department of \\ Criminalistics, Saint Petersburg, Russia \\ ${ }^{2}$ Saint Petersburg Academy of the Investigative Committee of the Russian Federation, Department of \\ Preliminary Investigation of the Faculty of Advanced Training, Saint Petersburg, Russia
}

\begin{abstract}
Currently, there is a natural and labor migration, which is also the reason for the growth of crimes committed by foreigners. The purpose of the study is to make a complete algorithmized design of the organizational and procedural measures integrated into the methodology of investigation of any crime, the subject of which is a foreigner. Research methods: analysis of statistical data, survey, analysis and synthesis of comparative research of criminal cases, legal rules, fundamental scientific research, deduction. The novelty of the results: in the work, an algorithm in a synthesized form is created, which can be applied without additional processing by an employee of any law enforcement agency that investigates a crime committed by a foreigner.
\end{abstract}

Keywords: crimes, criminals, foreigners, migrants, migrant workers

\section{Introduction}

Megacities and large cities attract low-skilled segments of the population of foreign countries, especially neighboring countries, to perform work and provide services. This group of individuals is also a source of security threats. In this case, migrant crime. The following fundamental studies were prepared on this topic: Aleksandrova "Investigation of criminal cases involving foreigners. Issues of tactics and organization of investigation" [1], Ivashchuk "Investigation of crimes committed by foreign citizens or with their participation" [2], Sizov "Features of pre-trial proceedings in cases of crimes committed by foreign citizens" [3], Foigel "Scientific bases of forensic methods of investigation of advenal crimes" [4], Guild and Baldaccini "Terrorism and the foreigner: a decade of tension around the rule of law in Europe" [5].

At the same time, the volumes of these studies are significant, they contain general scientific conclusions [1-5], which need additional transformation for the tasks of law enforcement. The novelty of the results of this study: the actions and decisions that the law enforcement officer will have to implement if the crime is committed by a foreigner. The

\footnotetext{
* Corresponding author: lantuh71@ mail.ru
} 
hypothesis of the study: any crime committed by a foreigner contains an organizational and legal constant, which is the quintessence in the forensic methodology of the investigation of each crime, committed by a foreigner. The purpose of the study is to make a complete algorithmized design of the organizational and procedural measures integrated into the methodology of investigation of any crime, the subject of which is a foreigner. The objectives of the study: to identify the problematic aspects of the organization of the investigation; to articulate ways to deal with problems.

\section{Methods}

Research methods: analysis of statistical data, survey, analysis and synthesis of comparative research of criminal cases, legal rules, fundamental scientific research, deduction.

\section{$3 \quad$ Results}

As a result of the implemented methods, the authors identified the tasks that are solved in each case when a foreigner commits a crime. The data is presented in the table.

Table 1. Tasks and methods.

\begin{tabular}{|c|c|c|}
\hline No. & $\begin{array}{l}\text { The quintessence of the } \\
\text { tasks to be solved }\end{array}$ & Method of solving the problem \\
\hline \multicolumn{3}{|c|}{ The stage of initiation of a criminal case } \\
\hline 1. & $\begin{array}{l}\text { Identification of the } \\
\text { foreigner }\end{array}$ & $\begin{array}{l}\text { 1) Study of the passport. } \\
\text { 2) If there is no passport, it is necessary to examine any documents } \\
\text { available: migration card; patent, and cheques confirming its } \\
\text { payment. } \\
\text { 3) Request data from the "Migrant" automated information base } \\
\text { from the duty station. } \\
\text { 4) If the person does not report anything about himself/herself, } \\
\text { then organize fingerprinting and fingerprint verification. If a } \\
\text { foreigner has become a suspect, then fingerprinting is mandatory. } \\
\text { 5) Send the dactocard to the IC of the Main Directorate of the } \\
\text { Ministry of Internal Affairs for the constituent entity of Russia and } \\
\text { the Main Information and Analysis Center of the Ministry of } \\
\text { Internal Affairs of Russia for checking the records. Consider that } \\
\text { its data may be different in the databases in terms of the translation } \\
\text { (for example: "Kadyrov" or "Kodyrov", writing in the first name, } \\
\text { last name with double letters). } \\
\text { 6) After the initiation of a criminal case, conduct a search at the } \\
\text { place of residence of the person. }\end{array}$ \\
\hline 2. & $\begin{array}{l}\text { Providing an interpreter } \\
\text { to a foreigner }\end{array}$ & $\begin{array}{l}\text { Call an interpreter from the services of court interpreters (court } \\
\text { translations). These are limited liability companies. Send a request } \\
\text { to the company with which the contract is concluded. The } \\
\text { translator shall: } \\
\text { 1) present the certificate of the relevant translation service; } \\
\text { 2) fill out a questionnaire indicating the languages that he/she } \\
\text { speaks orally and in writing; } \\
\text { 3) sign a warning under Article } 310 \text { of the Criminal Code of the } \\
\text { Russian Federation for disclosing the data of the preliminary } \\
\text { investigation. }\end{array}$ \\
\hline 3. & $\begin{array}{l}\text { The fact of the legality } \\
\text { of the presence of a }\end{array}$ & $\begin{array}{l}\text { 1) Study the passport of a foreigner (marks on crossing the state } \\
\text { border of Russia) and the migration card. }\end{array}$ \\
\hline
\end{tabular}




\begin{tabular}{|c|c|c|}
\hline & $\begin{array}{l}\text { foreigner on the } \\
\text { territory of Russia }\end{array}$ & $\begin{array}{l}\text { 2) If a person is illegally on the territory of Russia, decide on the } \\
\text { allocation of materials on the fact of the illegality of crossing the } \\
\text { state border. } \\
\text { 3) When interrogating a foreigner, find out: } \\
\text { a) why did he/she enter the territory of the Russian Federation? } \\
\text { b) how long has he/she been in the territory of the Russian } \\
\text { Federation and in which constituent entities has he/she lived? } \\
\text { c) where he/she actually lives, on what grounds, with whom; } \\
\text { where is the contract of employment? } \\
\text { d) is there a family (dependents), where, its composition; how } \\
\text { does he/she support these persons? } \\
\text { e) where, by whom, and in what period did he/she work (works), } \\
\text { how does he/she receive the salary, and in what amount? }\end{array}$ \\
\hline \multicolumn{3}{|r|}{ Preliminary investigation stage } \\
\hline 1. & $\begin{array}{l}\text { Fictitious nature of } \\
\text { registration at the place } \\
\text { of residence (stay) }\end{array}$ & $\begin{array}{l}\text { 1) The foreigner explains this fact. } \\
\text { 2) Data on the place of registration is contained in the "Migrant" } \\
\text { information base for a foreigner. The place of registration and } \\
\text { actual residence may be different. Send a request to the territorial } \\
\text { Department of Internal Affairs on migration issues. When making } \\
\text { procedural decisions, it is necessary to follow the response to the } \\
\text { request. } \\
\text { 3) Interrogate persons residing at the address of the fictitious } \\
\text { registration of the foreigner. } \\
\text { 4) If the registration at the place of residence (stay) is fictitious, } \\
\text { then make a decision on the allocation of materials under Article } \\
322.2 \text { or } 322.3 \text { of the Criminal Code of the Russian Federation } \\
\text { (depending on what was fictitious) and send it for decision- } \\
\text { making. }\end{array}$ \\
\hline 2. & $\begin{array}{l}\text { Arrest on suspicion of } \\
\text { committing a crime }\end{array}$ & $\begin{array}{l}\text { 1) If there are grounds and conditions for detention, it is } \\
\text { mandatory to detain. } \\
\text { 2) If the sanction of the article does not provide deprivation of } \\
\text { liberty, then it is necessary to explain to the person that he/she will } \\
\text { not be deprived of liberty and he/she will not be detained. The } \\
\text { defender should explain this through an interpreter. } \\
\text { 3) The ambassador or consul notified of the detention is entitled } \\
\text { to meet with the citizens of their country, and may also participate } \\
\text { in court hearings held in cases against them. }\end{array}$ \\
\hline 3. & Preventive measure & $\begin{array}{l}\text { 1) If there are grounds for the application of a preventive measure, } \\
\text { there is a need to initiate a petition for the detention of a person. } \\
\text { As a rule, the reason for choosing this measure is that a person can } \\
\text { hide from the investigation (inquiry). Facts: } \\
\text { a) the gravity of the charge and the possibility of imposing a } \\
\text { sentence of long-term imprisonment (but only at the initial stage } \\
\text { of the proceedings); } \\
\text { b) the presence of citizenship of a foreign state; the absence of a } \\
\text { permanent place of residence, work, or family in Russia. } \\
\text { 2) In the application, it is necessary to justify the impossibility of } \\
\text { choosing as an alternative - the prohibition of certain actions. }\end{array}$ \\
\hline 4. & $\begin{array}{l}\text { Figuring out a } \\
\text { foreigner's mental state }\end{array}$ & $\begin{array}{l}\text { Appoint a forensic psychiatric examination as soon as possible } \\
\text { after the initiation of a criminal case. There may be no } \\
\text { documentary data about his/her mental state both at the person and } \\
\text { in Russia. The presence of an expert opinion on the issues of } \\
\text { forensic psychiatric examination in relation to a person may not } \\
\text { allow expecting a response to an international request for legal } \\
\text { assistance in the future. }\end{array}$ \\
\hline
\end{tabular}




\begin{tabular}{|c|c|c|}
\hline 5. & $\begin{array}{l}\text { Request } \\
\text { international } \\
\text { assistance }\end{array}$ & $\begin{array}{l}\text { The request is usually sent to present the characterizing material } \\
\text { to a foreigner. Preparation and direction should be decided } \\
\text { immediately if a particular foreigner is found to be involved in the } \\
\text { crime. The absence of a response to the request is not an } \\
\text { independent reason for extending the investigation period } \\
\text { provided there is sufficient evidence indicating the involvement } \\
\text { and guilt of the foreigner in the act. }\end{array}$ \\
\hline 6. & $\begin{array}{l}\text { Ensuring the appearance } \\
\text { of a foreigner and } \\
\text { preventing him/her from } \\
\text { leaving the territory of } \\
\text { Russia if he/she is not } \\
\text { taken into custody }\end{array}$ & $\begin{array}{l}\text { 1) Notify the territorial agency of the border service of the FSB of } \\
\text { Russia that the person is an accused. } \\
\text { 2) If a person is not an accused person and a preventive measure } \\
\text { is taken against him/her that is not related to detention, then it is } \\
\text { necessary: } \\
\text { a) to send a message to the regional division of the Department of } \\
\text { Internal Affairs for Transport that a particular foreigner is a } \\
\text { suspect, he/she is not in custody, and in this regard, it is necessary } \\
\text { to notify carriers of passengers on air, rail, and water transport that } \\
\text { if he/she purchases tickets, it is necessary to immediately notify } \\
\text { both the Department of Internal Affairs for Transport and the } \\
\text { investigator (inquiry officer) by a specific phone number. But a } \\
\text { person can leave the territory of Russia from the territory of } \\
\text { another constituent entity of the Russian Federation; } \\
\text { b) send a message to the territorial body of the border service of } \\
\text { the FSB of Russia that a particular foreigner is a suspect, he/she is } \\
\text { not in custody, and if he/she leaves the territory of Russia, it is } \\
\text { necessary to immediately notify the investigator (inquiry officer) } \\
\text { by a specific phone number. }\end{array}$ \\
\hline 7. & $\begin{array}{l}\text { Compensation } \\
\text { damages }\end{array}$ & $\begin{array}{l}\text { 1) Take measures aimed at identifying the property at the expense } \\
\text { of which the damage can be compensated, as well as take } \\
\text { measures aimed at finding the property that can be confiscated. } \\
\text { 2) In the course of a search at the place of residence of a foreigner, } \\
\text { establish the property belonging to him/her, seize it and place it } \\
\text { under arrest. } \\
\text { 3) When establishing the place of work of a person who has } \\
\text { committed a crime, request data on how salaries are calculated, } \\
\text { send a request to the court to seize the money of the suspect } \\
\text { (accused) in the amount to be recovered. }\end{array}$ \\
\hline 8. & $\begin{array}{l}\text { The presence of the fact } \\
\text { of illegal labor activity }\end{array}$ & $\begin{array}{l}\text { Send a submission to the State Labor Inspectorate and the Federal } \\
\text { Tax Service about measures against the employer }\end{array}$ \\
\hline 9. & $\begin{array}{l}\text { Familiarization with the } \\
\text { case materials and } \\
\text { translation of the } \\
\text { indictment }\end{array}$ & $\begin{array}{l}\text { 1) The decision on the involvement as an accused - the transfer } \\
\text { shall be resolved immediately after the preparation of this } \\
\text { document. } \\
\text { 2) Familiarization with the materials of the case - to warn the } \\
\text { interpreter in advance and prevent him/her from leaving the } \\
\text { territory of the place of investigation. } \\
\text { 3) The indictment - shall be made in advance to ensure the timely } \\
\text { translation. The indictment shall be translated before getting } \\
\text { acquainted with the case. }\end{array}$ \\
\hline
\end{tabular}

\section{Discussion}

In relation to the analysis of the results obtained and the comparison of the data obtained with relevant studies published over the past five years, it is worth mentioning that Drozdova and Kudryashov [6] and Kobets [7] focus on preventing measures, including it partially in the investigation methodology since prevention issues also follow from the criminal procedure 
law. Markova, Koshelev and Sukhodolov focus on the analysis of migration crime with a number of conclusions [8] only for the formation of a forensic methodology. The same aspects were considered by Rashitov [9]. Some authors focus on actions and decisions that follow the stage of implementation of measures of forensic methodology $[10,11]$ and are directly related to the impact on the subjects of criminal acts. Foigel as in the monograph [12] as in co-authorship with his scientific adviser [13] directly considers the formation of forensic methods, but unlike the authors of this publication, does not make clear recommendations for the implementation of specific measures. Foreign authors $[14,15]$ consider the forensic methodology with regard to the local factor and domestic legislation, which does not fully correspond to the Russian reality.

\section{Conclusion}

The authors focus on the essence that shall be considered when designing the algorithm of organizational and procedural actions in cases of crimes committed by foreigners. The use of the above quintessence allows optimizing the work of investigators (inquiry officers) without losing the quality of the work itself.

There are no restrictions on the use of the results obtained. The authors believe that further study of the relevant topic is promising, as global migration processes continue. Further research can be focused on identifying the ethnic features of the relations of certain nationalities and their cultural characteristics, which shall be considered when organizing individual procedural actions. There may also be a need to create separate methods related to the investigation of crimes, the subjects of which are employees and workers of diplomatic missions and consular institutions [16].

\section{References}

1. O.I. Aleksandrova, Rassledovanie ugolovnykh del s uchastiem inostrantsev. Voprosy taktiki i organizatsii rassledovaniya [Investigation of criminal cases involving foreigners. Issues of tactics and organization of the investigation] (European House, Saint Petersburg, 2002)

2. V.K. Ivashchuk, Rassledovanie prestuplenii, sovershaemykh inostrannymi grazhdanami ili $\mathrm{s}$ ikh uchastiem [Investigation of crimes committed by foreign citizens or with their participation], $\mathrm{PhD}$ thesis (Moscow, 2008)

3. A.A. Sizov, Osobennosti dosudebnogo proizvodstva po delam o prestupleniyakh, sovershaemykh inostrannymi grazhdanami [Features of pre-trial proceedings in cases of crimes committed by foreign citizens], PhD thesis (Voronezh, 2006)

4. E.I. Foigel, Metodika rassledovaniya advenalnykh prestuplenii: teoreticheskaya model i mekhanizm realizatsii [Methods of investigation of advenal crimes: a theoretical model and a mechanism of implementation], PhD thesis (Rostov-on-Don, 2019)

5. E. Guild, A. Baldaccini, Terrorism and the foreigner: a decade of tension around the rule of law in Europe (Martinus Nijhoff publishers, Leiden, 2007)

6. E.A. Drozdova, O.V. Kudryashov, Gaps in Rus. Legisl. 3, 311-314 (2018)

7. P.N. Kobets, Osobennosti preduprezhdeniya prestupnosti inostrannykh grazhdan i lits bez grazhdanstva v Rossii [Features of crime prevention of foreign citizens and stateless persons in Russia] (Ekzamen, Moscow, 2006)

8. O.A. Markova, M.S. Koshelev, Ya.A. Sukhodolov, Rus. J. Crim. 12(2), 211-219 (2018) 
9. R.L. Rashitov, Bul. Kazan Law Inst. of the Min. of Internal Aff. Rus. 1, 124-128 (2016)

10. V.B. Pervozvansky, Yu.N. Strogovich, R.M. Zhilyaev, Gaps in Rus. Legisl. 3, 296-298 (2018)

11. S.Kh. Shamsunov, R.M. Zhilyaev, Person: Crime and Punish. 27(3), 295-299 (2019). https://doi.org/10.33463/1999-9917.2019.27(1-4).3.295-299

12. E.I. Voigel, Bul. Rus. Acad. of Law 3, 30-36 (2018)

13. A.A. Protasevich, E.I. Foygel, Rus. J. Crime 12(4), 485-495 (2018)

14. R. Bellelli, International criminal justice: law and practice from the Rome statute to its review (Routledge, 2016)

15. R. Mehta, Women, mobility and incarceration: love and recasting of self across the Bangladesh-India border (Routledge, 2018)

16. E.V. Lantukh, V.E. Schunk, J. Leg. and Ec. Stud. 3, 60-63 (2020) 